Originalveröffentlichung in: Peter Schäfer, Hans Kippenberg(Hg.), Envisioning Magic. A Princeton Seminar \& Symposium (Studies in the history of religions 75), Leiden 1997, S.

\title{
MAGIC AND THEOLOGY IN ANCIENT EGYPT
}

\author{
Jan Assmann
}

Magic is the best theology, for in it the true faith is both grounded and found. And he is a fool that reviles it, for he knows it not, and blasphemes against both god and himself, and is more a juggler than a theologian in understanding.

Jacob Boehme

I would like to start by defining the two notions that form the title of this article, that is, 'magic' and 'theology'. I am not claiming that these definitions will be generally applicable, they are only meant with regard to Egypt and with regard to some phenomena which might be very specific. By 'magic' and 'theology' I am going to understand two discourses which are defined both by function and by content or theme.

The 'theological discourse' is a late phenomenon. It arises in the New Kingdom (15th-12th centuries BCE) around one particular problem which is the concept of the Highest God or Supreme Being and his/her relation to the other members of the pantheon. ${ }^{1}$

I I would like to insert here a brief historical footnote. We have to distinguish between three different notions of polytheism. One which we may call absolute polytheism assumes the existence of many gods who are equal to, and independent from, each other in that they are all self-generated and immortal. The other, which may be called relative polytheism assumes the existence of many gods but of only one primordial and self-generated god on whom all the other gods are dependent. The third form of polytheism knows only gods that are mortal and immanent; this form, which corresponds to Hornung's view of Egyptian religion might be called immanent polytheism. This distinction goes back to the 17th century and is due to Ralph Cudworth who in his book The True Intellectual System of the Universe (1678) attempted to prove that all pagan religions had to be classified as relative polytheisms in that they acknowledged the existence of one supreme being. Moreover, he showed that atheism is the negation either of monotheism or of relative polytheism, but never of absolute polytheism. Atheism negates the existence of a Supreme Being. According to Cudworth, the recognition and worship of a unique supreme being, therefore, is common to all known religions and might be recognized as a natural and universal form of religion. As far as ancient Egypt is concerned, Cudworth was right, at least with regard to the New Kingdom and the Late Period when the concept of a Supreme Being starts to find a richly differentiated expression in the written documentation. 
The relation or even tension between One Supreme Being and a pantheon of many gods constitutes a problem that has no equivalent in monotheistic religions. The widespread prejudice that theology is the exclusive achievement of Biblical, if not Christian, religion is, therefore, unfounded with regard to ancient Egypt. On the contrary, Egyptian theology is much more elaborate than anything that can be found in the Bible. On the other hand, it is not simply coextensive with Egyptian religion. The first texts which might properly be called theological and which might count as representing an early stage of what in the Ramesside Period will become a well established and flourishing discourse date from the 18th dynasty. ${ }^{2}$ The emergence of this discourse has obviously much to do with the professionalisation of priesthood in Egypt and the increasing importance of literacy in Egyptian religion. Its development and rapid expansion, however, has to be seen in connection with what I have called the 'crisis of polytheism', that is, the religious developments leading to the monotheistic revolution of Akhenaten and its subsequent refutation. ${ }^{3}$ The literary genre which serves as the dominant medium for the theological discourse is the hymn addressing this highest god. Such hymns are attested in many different functional contexts. The most important context is, of course, the temple cult, where these hymns are sung as part of the daily or festive liturgy. Another very important context is the private tomb where the owner usually depicts himself at the entrance adoring the sun god with hymns. A third context is provided by literature, that is, manuscripts that were to be composed, learned by heart and copied in school or which circulated within the literate elite of the New Kingdom. ${ }^{4}$ Among the remaining contexts is magic, and this point of intersection forms the topic of my talk. Theology can thus be characterized as a kind of discourse that is closely defined with regard to theme but rather open with regard to function.

2 The famous paragraphs at the end of the Instruction for Merikare dealing with the creator who cares for his creation like a good shepherd anticipate the general scope and many motifs of the later Theological Discourse but they do not constitute a text of their own but are embedded into a wisdom text. But Papyrus Cairo 58038 might count as a forerunner of the theological discourse. The manuscript itself dates from the time of Amenophis II but the text might be older. Parts of it appear on a statuette in the BM which is said to date from the 17th dynasty.

${ }^{3}$ Cf. Egyptian Solar Religion in the New Kingdom. Re, Amun, and the Crisis of Polytheism, London 1995.

${ }^{4}$ The above-mentioned pBM 58038 seems to be such a literary manuscript. 
Magic, in contrast, is a kind of discourse that is rather open with regard to theme but closely defined with regard to function. Functionally, magic is to be defined as religion applied to the domestic sphere. This definition does not correspond to any Egyptian term nor can it be generalized. ${ }^{5}$ It corresponds to a practical rather than conceptual differentiation. As such, it meets a class of objects such as papyri, amulets, statuettes, stelae and so forth which stands out clearly enough from the mass of Egyptian material to be classified as magical. As far as texts are concerned, the hallmark of magic, that is, of private use are the directions for use and a formula of self-advertisement such as 'proven efficient a million times'.

There has never been any kind of tension or even antagonism between the temple cult and domestic religion. This is one of the reasons why there are no terms for each of them. The Egyptian term heka, copt. hik, which we usually translate as magic has obviously nothing to do which this distinction between temple and private use. If we start from Egyptian terminology, we get a totally different notion of magic. Magic in the sense of heka means an allpervading coercive power - comparable to the laws of nature in its coerciveness and all-pervadingness - by which in the beginning the world was made, by which it is daily maintained and by which mankind is ruled. Magic in the sense of a particular discourse is much more specific. It refers to the exertion of this same coercive power in the personal sphere.

We may thus distinguish between magic in the general sense and magic in the specific sense. Magic in the general sense of heka means coercive power; there is no possibility of opposing this term to anything like religion or the like. Moreover, the Egyptian term is morally neutral, as neutral as the laws of nature; power can be used for good as well as bad purposes. Magic in the specific sense of domestic application and personal use, on the other hand, can be opposed to religion. Magic in the specific sense of a discourse refers to power as effectuated not in the official and representative space of the temple but in the private space of the house, and not within the ritual time cycle but on a contingent occasion (but there might also be temporal

${ }^{5}$ This notion of magic comes close to E. Durkheim's definition of magic in his formes elementaires de la vie religieuse which, unfortunately, I can only quote in a German edition, see Die elementaren Formen des religiösen Lebens, Frankfurt: Suhrkamp, 1981, 69ff. For Egyptian magic see the excellent monograph by Robert K. Ritner, The Mechanics of Ancient Egyptian Magical Practice, Chicago 1993. 
prescriptions for magical rites). Magic is a religious act performed in a private house instead of the temple, for the sake of a private person instead of society, and on a specific occasion instead of within a cycle of calendaric events. The notion of 'private house' may be somewhat extended in the case of spells against crocodiles and other dangers, which are to be performed on the river or on the road. But the most typical functional context of magic, in Egypt, is medicine, and the physician is the normal magician. ${ }^{6}$ If we include in our notion of medicine also preventive devices such as spells against snakes, scorpions, crocodiles, disease-spreading daemons and the like, the notion of medical treatment comprises almost everything that can be called magical. There are, of course, many purely medical treatments that are not magical because they do not involve the divine and daemonic worlds. Egyptian Medicine comprises purely non-magical, partly magical and purely magical forms of treatments and provides the most typical functional context for those texts that form the magical discourse.

The religious practices to be performed in the official and representative space of the temple concern the cosmos and society as a whole and are therefore predominantly aimed at maintenance and stability. The attention of the priests is more directed towards the regular course of events and its stabilization than towards dealing with irregularities, calamities and crises. The management of the contingencies of daily life is delegated to the private sphere. This division of labor accounts for some thematical and structural peculiarities of magical texts. Their dominant attitude towards the divine sphere is not that of adoration and affirmation, but of exacting, constraining and even threatening. It makes a difference whether normality is to be maintained or a catastrophe is to be averted. The temple cult uses the same language when it comes to averting catastrophes. It is not the use of this kind of language which makes the difference, but the distinction between separate frames of application.

However, the temple cult is not primarily concerned with coercive power. Its dominant aspect is that of service. It addresses the divine in its local and political incarnation as lord/lady of a temple and town. In this incarnation, the divine has to be washed, dressed, anointed, feeded and addressed in the same way as the king in his palace. In this functional frame, theology is used for the composition

${ }^{6}$ See Friederike von Känel, Les prêtres ouab de Sekhmet et les conjurateurs de Serqet, Bibliothèque de l'École des Hautes Études sect. V, no. 87, Paris 1984. 
of laudatory addresses or hymns. The performance of these hymns is obviously not meant as a form of coercive incantation but as a form of pleasing entertainment of the gods. They take place in a sphere which is already sacred and inhabited by the divine. There is no need of using coercive power in order to 'presentify' the divine; it is already there, the place is already charged with divine presence which wants to be properly addressed and served. The divine has made the first step; cult is but a response. In the domestic sphere it is different. The divine is not there and needs to be presentified. The same hymns, when performed in the magical context, fulfil a different function. They no longer respond to the preceding apparition of the divine but serve as a means of its presentification. The text - without the alteration of a single word - loses its communicative meaning of service and assumes the coercive power of a presentifying incantation.

The relationship between magic and theology is very different from that between magic and myth. The use of mythological narratives in the context of magical sessions, especially healings is a typical and widespread phenomenon. In such cases, the mythological story functions as a precedence or model for the case in point. What happened to the mythical protagonist will happen to the patient. This is the usual form in which the figures of the divine world play a role in the magical texts. The use of theology, on the other hand, for magical purposes is rather exceptional. Theology is in many ways the opposite of mythology. Firstly, it is not narrative. The linguistic form of theology, in ancient Egypt, is appellative, that is, it is based on the concept of names and naming. Secondly, it is not constellative. This term needs some explanation. Mythological stories always imply several protagonists; they are intrinsically polytheistic. They depend on divine constellations such as father and daughter, father and son, husband and wife, king, courtiers and enemies, and so forth, which they unfold in the form of narrative episodes. Narration is based on action and action always implies constellations of actors and counteractors. It is precisely the aspect of action that is important in the magical context. Theology, on the other hand, concentrates on one god only, who is shown to surpass or transcend the world of divine constellations. This concept of god, therefore, is non-constellative. It implies neither actions, nor time in general, but refers to a timeless essence. ${ }^{7}$ The use of theology, that is, of texts or passages pertaining

\footnotetext{
${ }^{7}$ For these notions and distinctions cf. my book Egyptian Solar Religion in the Nerw
} 
to the theological discourse, in magical contexts is, as I have already said, rather exceptional. Moreover, in each of the cases which I have been able to collect, we are dealing with re-use. It seems obvious that the texts are taken from another functional context for which they had been originally composed in order to function in the context of magic. With myth, the situation is different. The stories themselves belong to oral tradition. Magic provides one of the most important occasions to put them to writing and to give them a literary form. In this case, magic is not re-using but using texts, which were composed for this purpose.

In this paper, I will deal with some of those magical spells which draw on topics of theology or which even employ whole hymns for their specific purposes. Our first example belongs in its overall structure to the genre of mythological incantations. It is a spell against the venom (mtwt) of scorpions or snakes or the like, known as 'the cunning of Isis'. Already the Egyptian title is full of theological allusions and implications: ${ }^{8}$

SPELLS FOR WARDING OFF POISON, FROM THE PRIMEVAL PERIOD $(z p t p j)$ WHEN BEINGS CAME INTO EXISTENCE AGAINST IT WHO KNEW ITS NATURE. POWERFUL IS THE GOD OUT OF WHOM IT ORIGINATED. WORDS SPOKEN BY SELQIS (the scorpion-goddess and patroness of medico-magicians): 'Spell of the divine god who came into existence by himself, who made heaven, the earth, the waters and the breath of life, gods, men, small cattle and large cattle, reptiles, birds, and fishes'.

This is a clear reference to the Egyptian concept of the highest god. His decisive properties are self-generation and creation. In this spell, pieces of theological discourse are embedded into the structure of a mythological narrative. The mythical narrative starts with a description of a primeval state when this god ruled over his creation, comprising gods and men alike:

The kingship over men and gods was one and the same matter, a period of many years ago. His name was unknown. Now he assumed many forms, and he fixed his names daily anew, as somebody with many names. One did not know this name, and one did not know that name.

Kingdom. Re, Amun, and the Crisis of Polytheism. Trans. A. Alcock. London and New York: Kegan Paul International, 1995.

${ }^{8}$ I am quoting pTurin 1993 in J.F. Borghout's translation: Ancient Egyptian Magical Texts. Nisaba 9, Leiden 1978, 51ff., No. 84. 
Isis however, being an extraordinarily clever woman, does not content herself with this state of affairs. She plans to get to know the true name of the Supreme god, her father. She forms a serpent out of earth and of the saliva, that her aged father let fall to the ground, and arranged things in a way that this serpent bit the god. The suffering god is told by Isis that she might cure him if he tells her his name, and he answers with the following piece of theology:

I am the one who made the heavens and the earth, who shaped the mountains, who created what is on it.

I am the one who made the water, so that the Great Swimming One (Methyer) came into existence.

I am the one who made the bull for the cow, so that lust came into existence.

I am the one who fashioned the heavens and made the horizon inaccessible after I had placed the bas of the gods in it.

I am the one who opens his eyes - and brightness comes into being, who shuts his eyes - and darkness comes into being.

According to whose order the inundation overflows, while the gods know not his name.

I am the one who made the hours so that the days came into being.

I am the one who divided the years, who created the seasons.

I am the one who made the living fire, in order to create the works of the house (k3wt pr).

I am Khepri in the morning, Re at noon, and Atum in the evening.

This passage reflects the highest standard of creation theology; put into the 2nd ps.sg. it would make a very beautiful hymn. But Isis sais: 'so your name was not among those you mentioned to me'. The god then whispers his true name into Isis' ears so that the reader is not going to learn it. But the telling of the story is obviously efficient enough to expell the venom. It closes with the words of Isis that release the god of his pain: 'Break out, scorpions! Leave Re! Eye of Horus, leave the god! Flame of the mouth - I am the one who made you, I am the one who sent you-come to the earth, powerful poison! See, the Great God has given his name away. Re shall live, the poison shall die. NN born of NN lives, the poison dies'.

The spell is to be recited over images of Atum-Horus-Hekenu (the name given here to the Highest god), of Isis and of Horus, and to be written on the hand of the patient who is supposed to lick it off.

This text illustrates in an emblematic way the decisive point of intersection between magic and theology: the divine name or names. The cryptonymity of the creator is a very traditional concept and 
much older than the theological discourse. The figure of the 'Hiddenof-name' appears already in the Old Kingdom. ${ }^{9}$ But it is only in the context of the Theological discourse that this notion is explained and developed. The creator's name is hidden because he originated by himself. The text shows that the Egyptian concept of 'name' includes what we would call 'epithets'. The whole series of epithets that forms the properly theological section of the spell is understood as a naming of names. A name in the Egyptian sense, therefore, is not only a mark of identification but also a description. For this reason, a whole hymn composed of descriptive epithets may count as a naming of names. This becomes clear by our next example.

The book entitled 'the twelve names of Horus'10 appears among other magical spells in Papyrus Chester Beatty VIII, dating from the XXth dynasty (about $1200 \mathrm{BC}$ ). ${ }^{11}$ It is to be recited every morning at sunrise and is to function as 'a great protection of all the bodily members'. It therefore belongs to the category of protective magic resp. preventive medicine as do all the other cases of reused theological texts. The idea is to provide the person for whom this spell is recited with a protection for every hour of the day. The text is too long to be quoted in full. What interests us in the present context is the concept of 'name' and the fact that these names refer not to the mythical actions and constellations of the solar circuit but to the timeless concept of a supreme Being. The following excerpt gives only the first sentences of each invocation:

1. Oh sublime falcon, who hides himself from his creation by the wisdom of his divine eye....

2. Oh sublime hawk, Ba-like one, in whose grip is eternity, the oldest of the gods whose Uraeus makes for him his protection....

3. Oh you who rise and shine in his disk, whose rays illumine, who is in the disk....

4. Oh you who originated by himself, who ascends into the air by means of his flame, who assembles himself unto the height of his arms.... with four faces on one neck....

\footnotetext{
${ }^{9}$ Jan Zandee, Der Amunshymnus des Pap. Leiden I 344 vso, 3 vols., (Leiden: Instituut voor het Nabije Oosten, 1992), 131-133.

${ }^{10}$ Annie Gasse, 'La litanie des douze noms de Re-Horakhty', in: Bulletin de l'Institut Français d'Archeólogie Orientale 84, 1984, 189-227.

11 A.H. Gardiner, Hieratic Papyri of the British Museum 3rd series, pls. 47-48, pp. 75-76.
} 
5. Oh old one who rejuvenates himself at his time, who gives light at his place, one god who became four gods (or: god of the gods), who engendered the twins....

6. Oh you jubilating in the midst of the radiance of Shu and Tefnut, you are sailing in triumph....

7. Oh sundisk inmidst the sky, whose power sits on the iron throne, great pillar who is never tired, to whom the sweet breeze of the north comes every day....

8. Oh great one who distances himself from mankind, great of terror for him whom he approaches, who has a human body with four ramshaped faces, who has one million ears and two million eyes....

9. Oh great of magic, sharp of magical power, who is conceived yesterday and born today, great secret lion chief of the western mountain, ruler and lord of eternity

10. Oh you who rise and sets in the primordial waters, who sets therein with his own body, who comes forth in his redness and his flame, oh you whose $\mathrm{Ba}$ is in his pupil, who becomes a child in the morning,

11. Oh secret $\mathrm{Ba}$ who rises in the primordial waters, who is nursed as a king by the two sisters

12. Oh oldest Horus, who became old in his bones, whom Seth grasps, whom Isis receives....

The specific invocations continue in the same vein and end with the formula: Hail to you, your name is such and such, for instance Atum, Ptah, Creator, Osiris, Khepre, Amun and so forth. The invocations refer to the god as hidden power and as cosmic manifestation. They characterize the sun god as supreme being, effectuating his daily course alone and not in form of a concerted effort of divine constellations, omnipotent, omniscient, eternal. The only constellations that are mentioned are those of creation when the primordial god in the act of becoming conscious of himself became a trinity-Atum, Shu and Tefnut; and the constellation of sunset, when the sungod is believed to enter the netherworld in the condition of death: then appear Seth and Isis. The liturgy of the twelve names reappears in a funerary papyrus of somewhat later date and in four temple inscriptions of greco-roman time, carefully collected by Annie Gasse. The temple is certainly its original home. The text must have been composed as a temple liturgy for the solar cult at some time before or after the Amarna revolution. Its use as a protective incantation for the sake of a private person is doubtlessly secondary. The idea is to evoke not a specific mythological event but the all-encompassing essence of the god as a supreme being in order to protect the person in a similarly 
allencompassing way against all possible dangers that might befall him in the course of the twelve hours of the day.

The liturgy of the twelve names of Horus has a close parallel in a greek magical text which occurs in the Great Magical Papyrus Paris (PGM IV 1596-1716). It is entitled he kata panton telete 'the initiation ceremony concerning everything', that is, conveying power over everything. The liturgy is a long hymn to the sun god to be spoken over a ring or phylactery in order to render it magically powerful. Lines 1648-1695 contain the different shapes and names which the sun god assumes in each of the twelve hours of the day, for example:

In the first hour, you assume the shape of a cat. Your name is Pharakuneth.

Give glory and favour to this amulet.

Another liturgy of this type not only gives the names and forms, but also the kind of tree, stone, bird and reptile that corresponds to eaeh hour. ${ }^{12}$ Again, the magical purpose is very general: 'for every action and for every thing which you want to obtain, invoke the god as follows ..... ${ }^{13}$

Our third example, the magical papyrus Harris dates from the same time period as the Turin papyrus containing the 'Cunning of Isis', that is, the later part of the 13th century BCE. It is an anthology of spells against crocodiles, collected for the use of travellors. Most of these spells are hymns to the god Shu in his quality of son and protector of the sun god. All these hymns belong to the sphere more of mythology than of theology because they refer to the constellation of the sun god and his divine bystanders, sailing in his boat over the sky and maintaining the world-order by overthrowing his enemies. This is a typical mythological event notwithstanding its taking place not in illo tempore but in the actual present. The magical function of its evocation is very obviously to direct the evil-expelling energies of the solar movement against the dangers, especially the crocodiles, threatening the traveller on the Nile. Among these hymns

12 PGM III 505-535; Reinhold Merkelbach and Maria Totti, Abrasax. Ausgewählte Papyri religiösen und magischen Inhalts. 3 vols. Abhandlungen der rheinisch-westfälischen Akademie der Wissenschaften, Sonderreihe Papyrologica Coloniensia. Opladen: Westdeutscher Verlag, 1990-1992, vol. II, 1-31.

${ }^{13}$ Merkelbach and Totti, Abrasax II, 10. 
are two that are presented as the hymns sung by the primordial ogdoad, the eight personifications of Chaos, in adoration of the selfgenerated god who emerged amongst them. A similar hymn of the Ogdoad is preserved in the Corpus Hermeticum. ${ }^{14}$ The second of these hymns is a hymnical praise of the solar circuit and belongs to the same mythology as the hymns to Shu.$^{15}$ But the first one is a classical example of theology. It runs as follows:

${ }^{14}$ The Hymn of the Ogdoas: C.H. XIII, 17-20 cf. XIII.3 and I.26; N.H.C. VI, 6.58-22-60, 1; C.H. XIII, 21.

${ }^{15}$ Words spoken by the Ogdoad from the first primeval time the Great ones, when they praised the god in their midst, his bones being silver, his flesh gold,

his hairdress of real lapislazuli.

The eight say:

Amun who hid himself in his pupil,

$\mathrm{Ba}$ who radiates with his eye,

with miraculous appearances, holy one whom nobody knows,

whose form shines, who hides himself in his eye,

secret of secrets, whose secret is not known,

praise to you up to the belly of Nut,

your children, the gods, worship you.

Maat unites herself to your secret cabin,

your mother Meret glorifies you.

When you let spring forth light at dawn

you encompass the lands with your rays.

when you lean upon the mountains in the west,

the inhabitants of the netherworld receive your light.

The crew of the chacals receives you

and tow your boat through the hidden mountain.

Your baboons, the eastern Bas,

jubilate at the rays of your disk.

the Bas of Buto and Hierakonpolis give homage to you,

your light shining in their faces.

You navigate over your two heavens without an opponent, your flaming breath has burned the evil one.

The red fishes are controlled by your boat, the abdu fish has announced to you the wenti-snake, the Ombite has fixed his spear in his body.

Heaven and earth tremble at his roaring,

his magic is powerful in overthrowing his enemies,

his spear of thirty cubits is sharp in the Evil one.

The earth god watches over him, he is his guard,

he grasps him and ties him up in his jail

your two eyes by which you are glorified devour him,

the devouring flame devours him in the fire

beginning at his head and ending at his feet.

They burn all his limbs in their flames.

You are sailing, your crew being in a propitious breeze.

The lake of two knives has become peaceful under you, your boat jubilates, your ways are widened, 
Hail, one who makes himself into millions whose length and breadth are limitless ${ }^{16}$ efficient power, who gave birth to himself uraeus with great flame great of magic with secret form secret ba, to whom respect is shown

King Amun-Re (1.p.h.), who came into being by himself Akhty, Horus of the east the rising one whose radiance illuminates the light that is more luminous than the gods

You have hidden yourself as Amun the great you have withdrawn in your transformation as the sun disk ${ }^{17}$ Tatenen, who raises himself above the gods

The Old Man always rejuvenating, travelling through nhh Amun, who remains in possession of all things this god who established the earth by his providence.

The text seems to be divided into three stanzas comprising 6,4 , and 6 verses respectively. The three stanzas refer to three different aspects of the Supreme God: the hidden and nameless power that transcends the world, the manifest ruler who governs the world, and the 'imperial triad' who hides itself within the world. The first stanza deals with the aspect of the hidden nameless power which can only be evoked by circumlocutions such as 'power' $(s h m)$, 'uraeus' (j'rtt), 'great of magic' (wr hk3w) and, finally, what has to be regarded as the nomen ipsum of this concept of god b3 st 3 'hidden ba'. ${ }^{18}$ As a nameless and secret ba the god is unlimited and omnipresent. The forms in which his power manifests itself are the million-fold Totality

since you have grasped that evil one.

The indestructible ones and the infatigable one, and the stars, they have landed in triumph.

Msqt receives you, your mother embraces you, when you approach the western horizon

the earth spreads its arms in order to receive you, all that is adores you.

${ }^{16}$ On the concept of the 'limitlessness' of god cf. 'who concealed himself, whose limits cannot be attained' vso ii, 8-9, Jan Zandee, Der Amunshymnus des Pap. Leiden I 344 vso, 3 vols., (Leiden: Instituut voor het Nabije Oosten, 1992), 120-126 (on 'without limits': p. 125). Cf. P. Berlin 3049, 16, 6 and Urk VIII, 116: 'whose circuit has no limits'.

17 This is one of the very few instances where the sun in other than Amarna texts is called Xprw of the god (cf. ch. 3, n. 7) and doubtless refers to the concept of the divine 'transformations' in which the sun forms the last stage of the cosmogonical and transformational process of the primeval god.

${ }^{18}$ Cf. Egyptian Solar Religion, 142-155. 
of Beings. The universe is less a creation than rather a transformation of this god: he made and makes himself into the 'millions', that is, the universe of forms which is interpreted here as a self-transformation or emanation of the One.

This stanza is quite different from the second one, which not only names the hidden god, but also emphasizes this name with cartouche and royal titles. There can scarcely be a clearer expression of the fact that the name too is only an aspect of the god, which he uses when he exercizes rule on the world. The middle stanza opposes this manifest aspect of immanence to the mysterious aspect of transcendence as dealt with in the first stanza. It pronounces the name and by doing so directs the cosmogonic force of the transcendent god against the enemy. This, at least, seems to be the magical function of the hymn as illustrated by a passage in another hymn which reads

Amun is a water charm when his name is pronounced on the Nun, the crocodile is powerless if his name is pronounced. ${ }^{19}$

The third stanza refers to a mediating concept between absolute transcendence and powerful immanence. It refers to the well known tripartite form of the supreme god as 'imperial triad', ${ }^{20}$ not in the form of his worldly manifestation, but in a threefold form of his hiddenness, which is revealed by the word play in the three divine names Amun, Aten and Tatenen. As Amun he has 'hidden himself' $(j m n)$; as the sun disk he has removed himself $(j t n) ;{ }^{21}$ as Tatenen he has elevated himself above the gods $(t m j)$. As the sun he is the god of time, periodically alternating within endless time as an old man and a youth; as Amun he is the breath of life 'ever present in all things'; as Tatenen he is both the earth and the demiurg, who has arranged the world according to his 'design'.

I think this hymn is a fair example of the high level of theology in Ramesside Egypt. It combines three aspects of the Supreme Being: the hidden trinity, which is immament in form of light, vivifying

\footnotetext{
19 pLeiden I 350 ÄHG 194, 13-14.

${ }^{20}$ Cf. Erik Hornung, Conceptions of God in Ancient Egypt. Ithaca: Cornell UP, 1982, $219-221$.

${ }^{21}$ Cf. Neschons = ÄHG no. 131, 86; the verb jtn is also attested elsewhere in Ramesside hymns, apart from word-play with jtn 'sun'; cf. P. Berlin 3049 IV 1 = ÄHG no. 127A, 63-64: Imn Row jrjj pt n b\#.f sHDw t\#wj/jtn.f sw m hrt n Dt; cf. also Sobek Re III, 22-23.
} 
breath and creative earth; the manifest ruler who maintains justice and order by means of royal incarnation and the limitless one who appears as a universe of million emanations. It is this pantheistic or even 'spinozistic' concept of the nameless One which is of particular interest. The figure of the 'One who made/makes himself into millions' is a familiar one in ramesside theology. It occurs in several variants none of which, however, antedates the 19th dynasty. My impression is, therefore, that this pantheistic concept of the Supreme God is the reaction to the monotheistic revolution of Akhenaten. This explains its function as far as theology is concerned. But what may be its magical function?

We have to wait until the Late Period in order to find an answer to this question. In the magical papyrus Brooklyn we find two vignettes showing a rather strange being with seven different heads. The accompanying text explains the picture as follows:

The 'Bes' with seven heads...

he is (embodies) the Ba's of Amun-Re, lord of Karnak, chief of IpetSut,

the ram with sublime face, who dwells in Thebes.

The great lion who generated by himself,

the Great god of the beginning,

the ruler of lands and the king of gods,

the lord of heaven, Earth, underworld, water and mountains

who conceals his name from the gods,

the giant of millions of cubits,

the strong.... who fixed the sky on his head,

of whose nose the air comes forth,

in order to animate all noses,

who rises as sun, in order to illuminate the earth,

of whose bodily secretions the Nile flows forth in order to nourish every mouth....22

Bes is a familiar figure in Egyptian magic. He is the god of the bed chamber who wards off the evil demons by means of his monstruous exterior. In this form, with his seven heads, he appears even more monstruous. In any event, he seems worlds apart from the sublime concept of a Supreme Being as it has been formed by Ramesside theology. Nevertheless, he is presented here as a universal deity embodying the seven Bas of Amun who is the highest god. We have

${ }^{22}$ Serge Sauneron, Le papyrus magique illustré de Brooklyn [Brooklyn Museum 47.218.156]. New York: The Brooklyn museum, 1970, 23 Tf. IV, fig. 3. 
to understand both the text and the picture on two levels. What the picture shows is the level of immanence, of the seven Bas, a combination of all the different manifestations in which the cosmogonic energy of the creator is present and operative in the world. What the text refers to is the level of transcendence, the ineffable and hidden universal god whom, of course, no image can represent. All the epithets which the text accumulates refer to Amun-Re, not to Bes. Bes is identified as the combined Bas of the Supreme God. It is Bes, who is shown in the image, but it is the supreme god who is referred to by the text. And the textual passage, again, is a fine piece of theology.

The other vignette of this papyrus shows a similar figure, but with nine heads instead of seven and two pair of wings instead of four. It stands upon an oval, encircled by a snake biting its tail $(s d \mathrm{~m} \mathrm{r} 3$, greek ouroboros) and containing several beasts that incorporate or symbolize evil powers: lion, hippopotamus, crocodile, snake, [scorpion, turtle] and dog. The accompanying text describes the picture, but without giving a theological interpretation.

With 9 faces on a single neck, a face of Bes, a face of a ram,

a face of a hawk, a face of a crocodile,

a face of a hippopotamus, a face of a lion, a face of a bull, a face of a monkey, and a face of a cat. ${ }^{23}$

This figure reappears on magical stelae such as the famous Metternich stela and becomes in fact quite common during the late Period. It is the same figure which in the Greco-Egyptian magical Papyri is called 'enneamorphos', the one with nine forms. ${ }^{24} \mathrm{We}$ may be sure that this is just another rendering of the same idea: a visualisation of the different forms, in which the cosmogonic energy of the supreme and transcendent god is present in the world. The Egyptian Pantheon is a composite form of this divine immanence. The seven Bas, the nine shapes or the million Beings are variant expressions of the same idea that god is one and many, one and all, Hen kai pan, as the Greek formula runs.

The magical purpose for which this highly theological concept of god is brought to function in the two vignettes of the magical Papyrus Brooklyn is as general and all-encompassing as the god himself.

${ }^{23}$ Sauneron, papyrus magique, 18, Tf. II, fig. 2.

${ }^{24}$ R. Merkelbach and M. Totti, Abrasax I, 78; II, 10f., III 59-65. 
The papyrus is designed as a general and unspecific protection against every possible form of danger.

In the greco-egyptian magical papyri, the share of theology becomes greater than that of mythology. Texts abound in names and epithets. Many of these theological passages display very much the same concept of a supreme god as that which we have met with in the Brooklyn papyrus, the concept of a hidden and universal supreme Being whose visible manifestation is the world:

Come to me, you from the four winds, god, ruler of all,

who have breathed spirits into men for life,

master of the good things in the world.

Hear me, lord, whose name is ineffable.

The daemons, hearing it, are terrified

the name BARBAREICH ARSEMPHEMPHROOTHOU-

and of it the sun, of it the earth, hearing rolls over;

Hades, hearing, is shaken; rivers, sea, lakes, springsd,

hearing, are frozen;

rocks, hearing it, are split.

Heaven is your head;

ether, body;

earth, feet;

and the water around you, ocean,

O Agathos Daimon.

You are lord, the begetter and nourisher and increaser of all. ${ }^{25}$

${ }^{25}$ PGM XII 238-245; Betz, 162. Cf. XIII, 762-794, Hans Dieter Betz, The Greek Magical Texts in Translation, Chicago 2nd ed. 1992, 190f.:

Come to me, you from the four winds,

ruler of all, who breathed spirit into men for life,

whose is the hidden and unspeakable name

it cannot be uttered by a human mouth-

at whose name even the daemons, when hearing are terrified,

whose is the sun, NNN, and the moon, NNN,

they are the unwearied eyes, shining in the pupils of men's eyes,

of whom heaven is head,

ether body,

earth feet,

and the environment water,

the Agathos Daimon,

You are the ocean, begetter of good things and feeder of the civilized world.

Yours is the eternal processional way in which your seven-lettered name is established for the harmony of the seven sounds [of the planets which] utter their voices according too the twenty-eight forms of the moon, NNN.

Yours are the beneficient effluxes of the stars,

daemones, and Fortunes, and Fates,

by whom is given wealth, good old age, good children, good luck; a good burial. 
In general, the magical discourse of the greco-egyptian papyri is fundamentally different from that of the traditional Egyptian sources. The range of domestic application seems to have become much larger. Many domains if not the whole of traditional religion seems to have made the shift from the temple into private houses. This becomes perfectly understandable with the closing of the temples, but the process of domesticisation ('Verhäuslichung') and privatisation of Egyptian temple religion must have started much earlier. ${ }^{26}$ Religion developed into an area where it ceased to be a system of representative actions meant to stabilize at the same time the cosmos and human society and became a system of individual stabilization, sanctification and power. This explains why the share of theology is so much more important in the greco-egyptian texts. We are now no longer dealing only with preventive medicine and protection, but with all kinds of sanctification ceremonies, mantics, shamanistic visions and so forth.

This last stage in the history of Egyptian religion where it became mixed with all kinds of individual religious and philosophical quest for salvation (Heilssuche) meant the final triumph of Ramesside pantheism, the One-and-million or Hen kai Pan.

As has been pointed out at the beginning of this paper, two forms of religious discourses stand out among the magical uses of religion. One is myth, the other theology. We are now able to functionally distinguish between 'applied mythology' and 'applied theology'. Applied mythology occurs where a specific case is to be treated and a specific problem to be solved. The specificity of the case is mirrored in the specificity of the mythical event which is told. Applied theology occurs where a general and all-encompassing protection is to be assured. Here, the unspecific nature of the desired protection is mirrored in the very universality and all-encompassing Oneness of the deity invoked.

And you, lord of life, king of the heavens and the earth and all things living in them,

you whose justice is not turned aside,

you whose glorious name the Muses sing,

you whom the eight guards attend,

NNN, you who have truth that never lies.

Your name and your spirit rest upon the good.

Come into my mind and my understanding for all the time of my life and accomplish for me all the desires of my soul.

${ }^{26}$ In a new book, David Frankfurter is coming to very similar conclusions concerning what he calls the 'localization' of Egyptian Religion in the 3rd and 4th centuries, see his Religion in Later Roman Egypt: Continuities, Transformations, and Christianization (provisional descriptive title). I am very grateful to David Frankfurter for having made accessible to me a first draft of part II where he deals with these questions. 
For these general purposes, the magicians had recourse to the concept of a 'theos pantheos', a god who comprised in his essence all the other gods and who created the world by becoming the world which is nothing other than his body. This god, however, is a hidden god, a deus absconditus et ineffabilis, who cannot be invoked because he has no name, nor can he be represented because he has no form and image. But his 'bau', the different forms of his immamenent presence and energy, can be bundled and represented in the shape of a composite deity, who appears as Bes pantheos in the Brooklyn Papyri and on the magical stelae and later also in the form of a lion with different heads whose Egyptian name is Twtw, in Greek Tithoes. These names and images refer to the polymorphous immanence of the God.

He himself, however, transcends the world in the same way as the soul transcends the body. This pantheistic idea of a cosmic god, le dieu cosmique, as J.-A. Festugière has called him, is common to many different discourses or frames of application such as Egyptian hymns since the 13th century, temple inscriptions from the Persian period down to Late Antiquity, Egyptian magical texts from the Ramesside period to Hellenism, the Corpus Hermeticum and the greco-egyptian Magical texts. ${ }^{27}$ All these various discourses are different applications of the same theology. Moreover, this concept of god corresponds very closely to the theology of Stoic and Neoplatonic philosophy. The god of the philosophers and the god of the magicians were one and the same. We are, therefore, not dealing with a specifically magical concept. On the contrary, we are dealing with the magical application of a common pantheistic theology.

${ }^{27}$ Re und Amun. Die Krise des polytheistischen Weltbilds im Agypten der 18.-20. Dynastie, Orbis Biblicus et Orientalis 51 (Fribourg und Göttingen: Freiburger Universitättsverlag and Vandenhoeck \& Ruprecht, 1979) 242-246; Egyptian Solar Religion, 174-178. 